\title{
Inhaled frusemide does not affect lung mucociliary clearance in healthy and asthmatic subjects
}

\author{
A. Hasani*, D. Pavia*, M.A. Spiteri*, C.T. Yeo**, J.E. Agnew*, \\ S.W. Clarke*, K.F. Chung**
}

Inhaled frusemide does not affect lung mucociliary clearance in healthy and asthmatic subjects. A. Hasani, D. Pavia, M.A. Spiteri, C.T. Yeo, J.E. Agnew, S.W. Clarke, K.F. Chung. CERS Journals Ltd 1994.

ABSTRACT: Inhaled frusemide has been shown to protect against the bronchoconstrictor effect of several inhaled agents in asthmatic subjects by mechanism(s) that are unclear. Since loop diuretics can modulate $\mathrm{Cl}^{-}$transport in the airway epithelium, frusemide may alter the quality and/or the quantity of the periciliary layer, which in turn may affect lung mucociliary transport.

We investigated the effect of a single inhalation of nebulized frusemide $(40 \mathrm{mg})$ on lung mucociliary clearance in four healthy subjects and in seven stable, mild asthmatics using an objective radioaerosol technique. Frusemide or placebo was inhaled in a double-blind, randomized, cross-over manner half an hour after the inhalation of $5 \mathrm{\mu m}$ polystyrene particles labelled with ${ }^{99 \mathrm{~m} T c}$, used for assessing mucociliary clearance.

The pulmonary function and initial radioaerosol distribution were similar between frusemide and placebo runs within each of the two study groups. The areas under the tracheobronchial retention curves over the $6 \mathrm{~h}$ observation period were similar between frusemide and placebo runs for both groups.

Our findings show inhaled frusemide, at a dose known to inhibit bronchoconstrictor responses, does not affect lung mucociliary clearance.

Eur Respir J., 1994, 7, 1497-1500.
Depts of *Thoracic Medicine and Medical Physics, Royal Free Hospital and **National Heart and Lung Institute, London, UK. †Present address: Boehringer Ingelheim (UK) Ltd, Bracknell, Berkshire, UK.

\author{
Keywords: Asthma \\ frusemide \\ mucociliary clearance \\ radioaerosol
}

\author{
Correspondence: A. Hasani \\ Dept of Thoracic Medicine \\ Royal Free Hospital \\ Pond Street \\ London NW3 2QG \\ UK
}

Received: July 151993

Accepted after revision May 101994
Inhaled frusemide inhibits the bronchoconstrictor effects of indirect challenges, such as allergens, distilled water, sodium metabisulphite and adenosine, in asthmatic patients [1-4]. Because frusemide has no effect against the bronchoconstriction induced by methacholine and histamine $[3,4]$, it is likely that it has no direct effect on airway smooth muscle, and that the effect of frusemide is to inhibit the release of mediators induced by indirect challenges [5].

Lung mucociliary clearance is one of the host defence mechanisms of the airways [6] and, together with the cough response [7], helps to keep the airways free of inhaled deposited insoluble material, as well as locally produced biological debris. Lung mucociliary clearance may be affected by a number of physiological, pharmacological, environmental and pathological factors [8]. In patients with mild stable asthma and those who are in clinical remission, lung mucociliary clearance is depressed, and the mechanisms by which this occurs are unclear $[9,10]$.

Loop diuretics, such as frusemide, inhibit the $\mathrm{Na}^{+} / \mathrm{K}^{+} /$ $2 \mathrm{Cl}^{-}$co-transporter in canine airway epithelium [11], and also reduce intracellular $\mathrm{Cl}^{-}$activity through a cotransport system in cultured human airway epithelium [12]. In addition, frusemide may increase the release of prostaglandins from the airway mucosa [13]. These factors may perturb the ionic milieu of the epithelial lining fluid, which could affect periciliary activity, which in turn could affect the mucociliary clearance mechanism. In addition, such changes could inhibit the releasability of mediators from inflammatory cells, which could underline the protective effect of frusemide against indirect challenges. We therefore investigated the effect of a single inhalation of nebulized frusemide, at a dose known to inhibit bronchoconstrictor responses on lung tracheobronchial transport efficiency, in normal subjects and in patients with stable asthma.

\section{Material and methods}

\section{Subjects and patients}

Seven stable asthmatics (one smoker) and four healthy subjects (two smokers) volunteered for the study (table 1). The asthmatic patients refrained from taking any bronchodilators for at least $8 \mathrm{~h}$ prior to their visit. The three smokers did not smoke for one hour prior to the inhalation of the radioaerosol, nor in the ensuing $6 \mathrm{~h}$. Informed written consent was obtained from each volunteer 
Table 1. - Physical characteristics, tobacco consumption and pulmonary function indices for the asthmatic and healthy subject groups

\begin{tabular}{|c|c|c|c|c|c|c|c|}
\hline Group & $\mathrm{n}$ & $\begin{array}{l}\text { Sex } \\
\text { M:F }\end{array}$ & $\begin{array}{l}\text { Age } \\
\text { yrs }\end{array}$ & $\begin{array}{c}\text { Smoking } \\
\text { habit }\end{array}$ & $\begin{array}{l}\mathrm{FEV}_{1} \\
\% \text { pred }\end{array}$ & $\begin{array}{l}\dot{\mathrm{V}} \max _{50} \\
\% \text { pred }\end{array}$ & Medication \\
\hline $\begin{array}{l}\text { Asthmatic } \\
\text { patients }\end{array}$ & 7 & $6: 1$ & $32 \pm 4$ & $\begin{array}{l}4 \mathrm{NS} \\
2 \mathrm{ES} \\
1 \mathrm{~S}\end{array}$ & $100 \pm 9$ & $73 \pm 10$ & $\begin{array}{l}5 \mathrm{~B}+\mathrm{St} \\
1 \mathrm{~B} \\
1 \mathrm{Nil}\end{array}$ \\
\hline $\begin{array}{l}\text { Healthy } \\
\text { subjects }\end{array}$ & 4 & $3: 1$ & $23 \pm 1$ & $\begin{array}{l}2 \mathrm{NS} \\
2 \mathrm{~S}\end{array}$ & $113 \pm 2$ & $105 \pm 9$ & - \\
\hline
\end{tabular}

Data are presented as mean \pm SEM. NS: nonsmoker; ES: ex-smoker; S: current smoker; M: male; F: female; $\mathrm{FEV}_{1}$ : forced expiratory volume in one second; $\dot{\mathrm{V}}_{\max }$ : $\operatorname{maximum}$ airflow at $50 \%$ vital capacity; B: inhaled salbutamol p.r.n.; St: regular inhaled steroid.

subject prior to the study, which was approved by the Royal Free Hospital's Ethics Subcommittee.

\section{Study design}

Each volunteer subject was studied on two occasions, separated by at least one week. On each occasion, subjects inhaled either a single dose of frusemide or vehicle placebo $30 \mathrm{~min}$ after inhalation of the radioaerosol in a double-blind, cross-over and randomized order. Forced expiratory volume in one second $\left(\mathrm{FEV}_{1}\right)$ and flow rates at $50 \%$ of vital capacity $\left(\dot{\mathrm{V}}^{\mathrm{max}}{ }_{50}\right)$ were measured using a dry bellows spirometer (Vitalograph $\AA$ ) and an Ohio 840 spirometer, respectively, $15 \mathrm{~min}$ prior to inhalation of the radioaerosol. The highest value from three technically acceptable measurements was recorded for each pulmonary function index.

\section{Mucociliary clearance}

Lung mucociliary clearance was measured using an objective, noninvasive radioaerosol technique [14]. Polystyrene particles ( $5 \mu \mathrm{m}$ in diameter) firmly labelled with the radionuclide ${ }^{99 \mathrm{~m} T c}$ were inhaled (via the mouth) in discrete breaths by the volunteer subjects, whilst seated, wearing a noseclip and under strictly controlled conditions.

Initial radioaerosol lung deposition and subsequent clearance was monitored with two suitably collimated scintillation counters, axially opposed anteroposteriorly over the mid-sternum [15]. A count was made immediately following inhalation of the radioaerosol to ascertain the initial lung deposition. Thereafter, counts were made at regular, half-hourly intervals for $6 \mathrm{~h}$, and a final count was made at $24 \mathrm{~h}$, to estimate the proportion of radioaerosol which was deposited in the nonciliated airways (alveolar deposition (AD)) and, therefore, unavailable for mucus clearance [16]. All counts were expressed as a percentage of the initial count, and alveolar deposition was subtracted from all readings to give a tracheobronchial retention curve. During the $6 \mathrm{~h}$ observation period, all coughs were recorded, and any sputum collected was weighed and its radioactive content (in terms of initial tracheobronchial deposition) was assessed.
The initial topographical distribution of the radioaerosol within the lungs was ascertained using a large fieldof-view gamma camera (Ohio 110) linked to a computer (Nuclear Diagnostic). A ventilation scan using $81 \mathrm{mKr}$ gas was performed in order to delineate the edges of the lungs and, thus, estimate radioaerosol penetration to the periphery (penetration index (PI)) [17].

\section{Drug administration}

Frusemide solution was prepared as $4 \mathrm{ml}$ of frusemide (injectable solution of $10 \mathrm{mg} \cdot \mathrm{ml}^{-1}$; Hoechst UK Ltd) mixed with $6 \mathrm{ml}$ of $0.9 \% \mathrm{NaCl}$. The placebo solution consisted of $10 \mathrm{ml}$ of $0.9 \% \mathrm{NaCl}$. Both the frusemide and placebo solutions were administered as aerosols using a disposable System 22 (Medic-Aid) nebulizer.

\section{Data analysis}

The data were not normally distributed and statistical analysis was assessed using the nonparametric paired and unpaired Wilcoxon tests [18]. Results are expressed as mean \pm SEM.

\section{Results}

There were no statistically significant differences between the two runs for $\mathrm{FEV}_{1}$ and $\dot{\mathrm{V}} \max _{50}$ within each group. Alveolar deposition for the placebo and frusemide were $44 \pm 4$ vs $45 \pm 3 \%$, respectively, for the asthmatic group; and $66 \pm 7$ vs $57 \pm 9 \%$ respectively, for the healthy group. Initial radioaerosol distribution (PI) was $0.69 \pm 0.05$ vs $0.60 \pm 0.06$ for the placebo and frusemide runs, respectively, in the asthmatics; and $0.80 \pm 0.05$ vs $0.74 \pm 0.04$, respectively, in the healthy group. There were no significant differences between the two runs for AD and PI within each group.

During the $6 \mathrm{~h}$ observation period, two of the healthy subjects had dry unproductive coughs: 13 (placebo) vs 12 (frusemide) in one subject, and 5 (placebo) vs 10 (frusemide) in the other. Two of the asthmatics did not cough on either run. The number of coughs for the remaining five asthmatics were similar: $4 \pm 1$ (placebo) vs 
a)

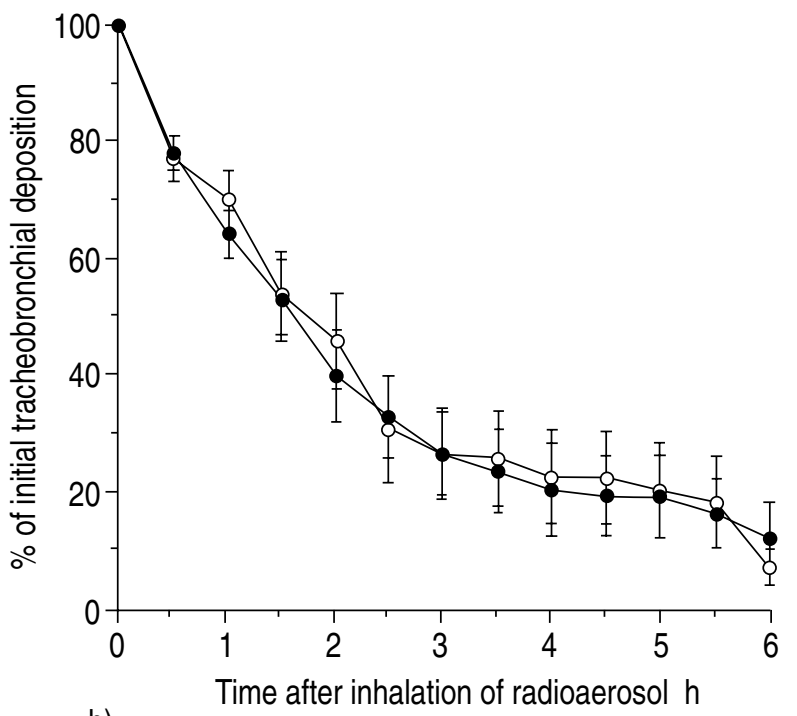

b)

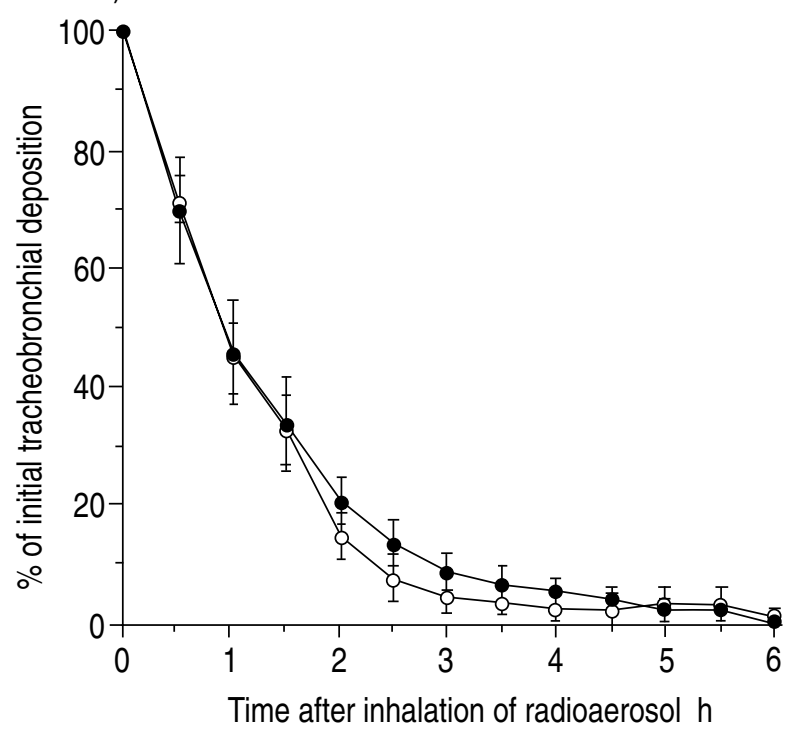

Fig. 1. - Tracheobronchial retention curves over $6 \mathrm{~h}$ for the placebo and frusemide runs for: a) seven asthmatics; and b) four healthy subjects. Data are presented as mean \pm SEM. -0 : placebo; $-0^{-}$: frusemide.

$4 \pm 2$ (frusemide) $(\mathrm{p}>0.10)$. One asthmatic produced 1.3 $\mathrm{g}$ of sputum containing $1.2 \%$ of initial tracheobronchial deposition in the frusemide run, and this patient and one other produced $1.3 \mathrm{~g}(2.8 \%)$ and $1.9 \mathrm{~g}(24.0 \%)$ of sputum, respectively, on the placebo run.

Figure 1 shows the mean tracheobronchial retention curves for the placebo and frusemide runs separately a) for the asthmatics; and b) for the healthy subjects. The areas under the tracheobronchial retention curves between 0-6 $\mathrm{h}\left(\mathrm{AUC}_{0-6}\right)$ for the asthmatics were $234 \pm 37$ (placebo) vs $227 \pm 35$ (frusemide) $\% \cdot \mathrm{h}^{-1}(\mathrm{p}>0.10)$ and for the healthy subjects $123 \pm 10$ (placebo) vs $134 \pm 16$ (frusemide) $\% \cdot \mathrm{h}^{-1}(\mathrm{p}>0.10)$. The $\mathrm{AUC}_{0-6}$ for the placebo run was statistically higher $(\mathrm{p}<0.05)$ for the asthmatic group compared to the healthy group, indicating a retardation in their tracheobronchial clearance.

\section{Discussion}

We have shown that inhaled frusemide, at a dose that is known to inhibit bronchoconstrictor responses in asthmatic airways, does not modulate mucociliary clearance in either normal subjects or asthmatic patients. The similarity in the initial deposition pattern between the two runs in both groups ensured that the direct comparisons of the tracheobronchial retention curves were valid. The number of productive and unproductive coughs were both small, and similar between the placebo and frusemide test days. Therefore, the measured tracheobronchial clearance was predominantly a reflection of mucociliary clearance [7].

Lung mucociliary clearance is influenced by several factors, including the integrity of the ciliated epithelium and the thickness and physical properties of the periciliary or mucous layer [6]. Frusemide inhibits the inward movement of chloride via an electrically neutral $\mathrm{Na}^{+} / \mathrm{K}^{+} / \mathrm{Cl}$ co-transporter in the basolateral membrane of canine epithelial cells [11], and reduce intracellular $\mathrm{Cl}^{-}$activity in human airway epithelial cells [12]. Such changes may lead to an increase in osmotic or ionic composition of epithelial lining fluid, which may in turn inhibit release of mediators from stimulated lumenal cells, such as mast cells. This may underline the mechanism by which frusemide inhibits the bronchoconstrictor effect of indirect challenges [5]. In addition, this change in the composition of the sol layer of the airway surface liquid may potentially lead to a reduction in mucociliary clearance. However, frusemide may also induce the release of prostaglandins, such as prostaglandin $\mathrm{E}_{2}\left(\mathrm{PGE}_{2}\right)$ [13], which is known to be a potent secretagogue [19], and ciliostimulator [20]. Our study suggests that the interactions between these potential effects of frusemide does not lead to changes in mucociliary clearance.

In our study, we have also demonstrated reduced lung mucociliary clearance in mild asthmatics compared to normal subjects, as reported previously $[9,10]$. The reduction in asthmatics is an underestimate of the time effect, because the radioaerosol was deposited on average more proximally within the lungs of asthmatics compared to normal volunteers. Thus, there was a shorter transit ciliated path for asthmatics compared to normals [21]. The mechanisms underlying this reduction in mucociliary clearance are unclear, but inflammatory mediators involved in asthma, such as slow-reacting substance of anaphylaxis (SRS-A), decrease clearance [22]. Frusemide has been shown to have the capacity to prevent the release of inflammatory mediators, such as leukotrienes, from passively-sensitized human lung in vitro [23]. However, we found no evidence that frusemide was active in reversing the reduced clearance observed in asthmatic patients, even at a dose that is known to inhibit allergen-induced acute response in asthmatics $[1,24]$. Studies of the protective effect of frusemide against airway challenges have been performed within $30 \mathrm{~min}$ of challenge, but in a study of its inhibitory effect against cough challenges, we found an effect lasting for up to $3 \mathrm{~h}$ [25]. In our present study, there was no effect on mucociliary clearance seen between 
30-60 min post-frusemide inhalation and during the ensuing $5 \mathrm{~h}$ observation period. In summary, a dose of inhaled frusemide, which is known to afford protective effect against airway challenges, has no effect on lung mucociliary clearance in patients with asthma. Whether it can modulate changes in lung mucociliary clearance induced by bronchoconstrictor challenge remains to be seen.

\section{References}

1. Bianco S, Pieroni MG, Refini RM, Rottoli L, Sestini P. Protective effect of inhaled furosemide on allergen-induced early and late asthmatic reactions. N Engl J Med 1989; 321: 1069-1073.

2. Robuschi M, Gamboro A, Spagretto S, Vaghi A, Bianco $S$. Inhaled frusemide is highly effective in preventing ultrasonically nebulised water bronchoconstriction. Pulmon Pharmacol 1989; 1: 187-191.

3. Nichol GM, Alton EWFW, Nix A, Geddes DM, Chung KF, Barnes PJ. Effect of inhaled frusemide on metabisulfite- and methacholine-induced bronchoconstriction and nasal potential difference in asthmatic subjects. $\mathrm{Am}$ Rev Respir Dis 1990; 142: 576-580.

4. O'Connor BJ, Chung KF, Worsdell M, Fuller RW, Barnes PJ. Effect of furosemide and bumetanide on adenosine 5-monophosphate- and sodium metabisulphiteinduced bronchoconstriction in asthmatic subjects. Am Rev Respir Dis 1991; 143:1329-1334.

5. Chung KF, Barnes PJ. Loop diuretics and asthma. Pulmon Pharmacol 1992; 5: 1-7.

6. Pavia D. Lung mucociliary clearance. In: Clarke SW Pavia D, eds. Aerosols and the Lung. London, Butterworth, 1984; pp. 127-155.

7. Hasani A, Pavia D. Cough as a clearance mechanism. In: Braga PC, Allegra L, eds. Cough. New York, Raven Press, 1989; pp. 39-52.

8. Pavia D, Bateman JRM, Clarke SW. Deposition and clearance of inhaled particles. Bull Eur Physiopathol Respir 1980; 16: 335-366.

9. Bateman JRM, Pavia D, Sheahan NF, Agnew JE, Clarke SW. Impaired tracheobronchial clearance in patients with mild stable asthma. Thorax 1983; 38: 463-467.

10. Pavia D, Bateman JRM, Sheahan NF, Agnew JE, Clarke SW. Tracheobronchial mucociliary clearance in asthma: impairment during remission. Thorax 1985; 40: 171-175.

11. Welsh MJ. Inhibition of chloride secretion by frusemide in canine tracheal epithelium. J Membr Biol 1983; 71: 219-226.
12. Williumsen NJ, Davis CW, Boucher RC. Intracellular $\mathrm{Cl}^{-}$activity and cellular $\mathrm{Cl}^{-}$pathways in cultured human airway epithelium. Am J Physiol 1989; 256: C1003C1044.

13. Pavord I, Knox A, Cole A, Tattersfield A. Effect of frusemide on release of prostaglandin $\mathrm{E}_{2}$ by bovine tracheal mucosa. Thorax 1991; 46: 751P.

14. Pavia D, Sutton PP, Agnew JE, Lopez-Vidriero MT, Newman SP, Clarke SW. Measurement of bronchial mucociliary clearance. Eur J Respir Dis 1983; 64: 4156.

15. Thomson ML, Pavia D. Long-term tobacco smoking and mucociliary clearance. Arch Environ Health 1973; 26: 86-89.

16. Camner P, Philipson K. Human alveolar deposition of $4 \mu \mathrm{m}$ Teflon particles. Arch Environ Health 1978; 36: 181-185.

17. Agnew JE, Pavia D, Clarke SW. Airways penetration of inhaled radioaerosol: an index to small airways function? Eur J Respir Dis 1981; 62: 239-255.

18. Siegel S. In: Nonparametric Statistics for the Behavioral Sciences. Tokyo, McGraw-Hill, 1956.

19. Marom Z, Shelhamer SH, Kaliner M. The effect of arachidonic acid, monohydroxyeicosatetraenoic acid and prostaglandins on the release of mucus glycoprotein from human airways in vitro. J Clin Invest 1981; 67: 1695-1702.

20. Wanner A, Maurel D, Abraham WM, Szepfalusi Z, Sielczak M. Effects of chemical mediators of anaphylaxis on ciliary function. J Allergy Clin Immunol 1983; 72: 663-667.

21. Thomson ML, Short M. Mucociliary function in health, chronic obstructive airway disease and asbestosis. J Appl Physiol 1969; 26: 535-539.

22. Ahmed T, Gerrnblatt DW, Birch S, Marchette B, Wanner A. Abnormal mucociliary transport in allergic patients with antigen-induced bronchospasm: role of slow-reacting substance of anaphylaxis. Am Rev Respir Dis 1981; 124: $110-114$.

23. Anderson SD, He W, Temple DM. Inhibition of frusemide of inflammatory mediators from lung fragments. $N \mathrm{Engl}$ J Med 1991; 324: 131.

24. Verdiani P, Di Stefania C, Baronti A, Bianco S. Effect of inhaled frusemide on the early response to antigen and subsequent change in airway reactivity in atopic patients. Thorax 1990; 45: 377-381.

25. Stone RA, Barnes PJ, Chung KF. Effect of frusemide on cough responses to chloride-deficient solution in normal and mild asthmatic subjects. Eur Respir J 1993; 6: 862-867. 